\title{
Impact of World Bank lending in an adjustment-led growth model ${ }^{\dagger}$
}

\author{
Sushanta Mallick* and Tomoe Moore**
}

* Department of Economics, Loughborough University, Loughborough LE11 3TU, UK; Email: s.k.mallick@lboro.ac.uk

** Coventry Business School, Coventry University, Coventry CV1 5FB, UK; Email: t.moore@coventry.ac.uk

\begin{abstract}
Within a financial- and growth-programming framework, this paper develops a policy-driven growth model and addresses the effects of World Bank lending on economic growth in a sample of 30 countries, after having controlled for the effects of key macroeconomic variables. Both static and dynamic panel estimates suggest a positive significant effect of the rate of growth in World Bank lending on economic growth, conditional on other variables, namely changes in exchange rate, domestic credit growth, and inflation. Empirical evidence also reveals the positive effect of a macroeconomic policy index in this sample of developing countries.
\end{abstract}

JEL classification numbers: F34, F35, O19

Keywords: World Bank lending, Aid-growth nexus, Developing regions

\footnotetext{
${ }^{\dagger}$ Thanks are due to Ayse Evrensel, Ali Kutan, Helena Marques, Eric Pentecost, Kunal Sen, and an anonymous referee for their helpful comments on an earlier version of this paper; and Huw Edwards and Tomas Kogel for useful discussions.
} 


\section{Introduction:}

The multilateral institutions, the IMF and the World Bank, play a significant role in determining the policy dynamics in many developing countries. As a result of the IMF supported economic reform program, many crisis hit countries in the 1990s have temporarily succeeded in achieving macroeconomic stabilization; ${ }^{1}$ and the existing studies suggest that IMF programs provide a short run balance of payments relief to crisis-hit countries. This effort however has been accompanied by temporary deceleration of real growth and prolonged recession in some countries. The major economic policy concern in the structural adjustment loans of the World Bank has been to stimulate growth based on a market oriented, export promotion strategy. Against this background, this paper attempts to examine the impact of the World Bank lending in bolstering sustained economic growth in developing countries. The World Bank loans have two key effects. First, it not only helps boost infrastructural investment (both social and physical), but also bank participation in investment projects may raise the expected level of both social and private investment returns thereby crowding in additional private sector investment (see Gilbert et al., 1999). Second, the lending also carries with it a package of structural policy reforms, which a country accepts as a condition for receiving the loan. Thus including World Bank lending as a variable in a growth model does reflect the impact of the loan size directly contributing to higher investment, and indirectly the associated reforms add further to economic efficiency and growth. Using the standard macroeconomic relationships of the IMF and the World Bank models, this paper derives a model of growth-oriented adjustment, which has then

\footnotetext{
${ }^{1}$ See Donovan (1982), Doroodian (1993), Conway (1994), Przeworski and Vreeland (2000), DicksMireaux and Schadler (2000), and Evrensel (2002).
} 
been used to estimate the impact of the World Bank's lending on economic growth in a sample of 30 countries.

There are a large number of empirical studies on the effectiveness of World Bank lending as spelt out in the next section. The overall results are inconclusive. Following the Harrod-Domar growth model, the more recent empirical literature is either, too general by using the data of aid or ODA (official development assistance) ${ }^{2}$ from multilateral institutions, or too specific by using the data of structural adjustment loans or only concessional credit by the World Bank. Loans used in the present study include all concessional and non-concessional World Bank lending ${ }^{3}$ over the period 1970-2001. Further, this is a balanced panel dataset and that the model is estimated without resorting to an average measure of four or five years for variables as often found in many empirical studies (e.g. Burnside and Dollar, 2000; Collier and Dollar, 2001). Bird and Rowlands (2001) examine the various mechanisms through which the World Bank loans may be associated with other financial flows, and find little support for a positive connection, but they did not look at the impact on economic growth. This paper specifically demonstrates the growth impact of increases in World Bank lending and explores the channels through which macroeconomic policies influence long-run growth in developing countries.

The major contribution of this study is the application of both static and dynamic panel techniques to estimate the impact of lending on economic growth while providing estimates for other policy variables in this sample of countries. This study

\footnotetext{
${ }^{2}$ Aid is defined as ODA. The type of aid on which we focus is loans given by the World Bank.

${ }^{3}$ The concessional loans are mainly from the International Development Association (IDA) and the nonconcessional loans are from the International Bank for Reconstruction and Development (IBRD). See section 4 for more details.
} 
employs a policy-based theoretical approach and models the impact of World Bank lending on economic growth, after having controlled for variables explaining macroeconomic stability and an aggregate policy index following Burnside and Dollar (2000). This coupled with using a balanced panel dataset may provide a better picture of the effectiveness of World Bank lending on growth than hitherto has been carried out.

It has been a long debate on the efficiency and effectiveness of World Bank lending, in particular, grant and debt cancellation programs, and that the future plan may involve the curtailment of these operations. However, empirical evidence in this paper reveals that in the framework of a model where macroeconomic policies are combined with economic growth, World Bank lending is effective in expanding a nation's productive capacity, hence promoting growth. This implies that further effort from donors' side is potentially an important factor to sustain the current aid operations.

The paper is set out as follows. The following section discusses the relevant literature. The third section develops an analytical model. The fourth section describes data and methodology, and discusses the results. The final section concludes.

\section{Existing evidence on the impact of World Bank lending}

\subsection{Evolution of the World Bank's lending strategies:}

The International Bank for Reconstruction and Development (IBRD) was initially referred to as the World Bank. In 1960, the International development Association (IDA) came into existence for the emergency of greater concern for poverty (Marcus, 2002) providing a highly concessional aid. Until the early 1970s, the World Bank was almost exclusively a project lending institution, lending in support of infrastructure and other projects, followed by policy-based lending in the late 1970s as a tool for 
reforming the policies of economic nationalism, referred to as structural adjustment loans (SALs). Under the SALs, financial flows to developing countries were made conditional on changes in policy, in order to adjust to the changing international economic environment and to restructure the economies (Mosley et al., 1991 and Krueger et al., 1999). In general, this type of policy was intended to reduce the level of government intervention in the economy. SAL conditionality covers wide-ranging policies, including trade, exchange rate, fiscal, industrial and competition policies, tax reform, energy and agricultural policy, financial sector reform, labour market policy, public sector efficiency and institutional reform (Bird and Rowlands, 2001; and Easterly, 2004). In addition to the SALs, the Bank introduced Trade Policy Adjustment Loans (TPALs) and Sectoral Adjustment Loans (SECALs) focusing on trade or any sector of the economy. These two forms of policy-based lending - SALs and SECAL - account for about a quarter of all World Bank disbursements (Mosley et al., 1991).

Decisions on the overall lending portfolios, in particular, for the poorer countries (which are eligible for subsidised loans) are based on a detailed set of subcriteria relating to macroeconomic performance, adjustment experience, the pricing environment, the performance of public institutions and of public policies in the welfare and poverty alleviation area (Mosley et al., 1991 and Easterly, 2004). This is broadly evidenced in the empirical work of Frey and Schneider (1986), who studied the lending behaviour of the World Bank ${ }^{4}$.

\footnotetext{
${ }^{4}$ Frey and Schneider (1986) found that the growth of the lagged GNP had a positive significant effect on IBRD and IDA loans per capita. The lagged inflation rate had negative significant coefficients. Moreover, they found a significant effect of political determinants such as the 'capitalist' climate or the political instability, and a former status of the recipient country as a colony or dominion. The results
} 


\subsection{Evidence for the Aid-Growth Nexus:}

Over the last two or three decades, much effort has been made to identify empirically the impact of multilateral lending on the economic growth and development of LDCs. The method ranges from detailed case studies at the project level to regression analyses of the growth impact of aid in samples of almost a hundred countries. So does the outcome of the empirical research on aid-growth ranging from no linkage to a positive linkage. Table 1 summarises the selective empirical literature on the effectiveness of aid on several aspects, which are directly or indirectly linked with growth. Note that 'aid' used here implies multilateral lending, which generally includes all loans from the World Bank, the IMF and all continental Development Banks (Bird and Rowlands, 2001) unless otherwise stated.

Table 1: Selective empirical studies of the Aid-Growth nexus

\begin{tabular}{|l|l|}
\hline Author & Finding \\
\hline \multicolumn{1}{|l|}{ 1. Does aid affect growth, investment and consumption? } \\
\hline Boone (1996) & $\begin{array}{l}\text { Aid has no impact on investment or growth with the panel } \\
\text { data of more than } 90 \text { countries. }\end{array}$ \\
\hline Easterly (1999) & $\begin{array}{l}\text { In the financing gap model } \\
\text { weak: the aid-investment link is very } \\
\text { significant link. }\end{array}$ \\
\hline $\begin{array}{l}\text { Hadjimichael } \text { et al. } \\
(1995) \text { and } \\
\text { Durbarry } \text { et al. } \text { (1998) }\end{array}$ & $\begin{array}{l}\text { In a neoclassical approach, aid is positively related to } \\
\text { growth, but with decreasing marginal returns to aid flows. }\end{array}$ \\
\hline $\begin{array}{l}\text { Obstfeld (1999) } \\
\text { In a neo-classical growth model, aid is positively related to } \\
\text { growth rates, investment and consumption, provided that } \\
\text { the economy is below the steady state. }\end{array}$ \\
\hline
\end{tabular}

suggest that the behaviour of this international organization is explained by economic, political and cultural factors.

${ }^{5}$ In the financing gap model, first, investment requirements to achieve a given growth rate are proportional to the growth rate by a constant known as the ICOR (Incremental Capital Output Ratio) - a fixed linear relationship between growth and investment. Second, aid goes into investment one for one. 


\begin{tabular}{|c|c|}
\hline $\begin{array}{l}\text { Lensink and Morrissey } \\
(2000)\end{array}$ & $\begin{array}{l}\text { While measuring aid volatility, there is a significant } \\
\text { positive impact of aid on growth via its effect on the } \\
\text { volume of investment. }\end{array}$ \\
\hline \multicolumn{2}{|l|}{ 1.1 SALs and growth: } \\
\hline Mosley et al (1991) & $\begin{array}{l}\text { In the country-specific case studies, the SALs have had } \\
\text { only a weak effect on real GDP growth, and it has had a } \\
\text { negative effect on investment. }\end{array}$ \\
\hline $\begin{array}{l}\text { Bird and Rowlands } \\
\text { (2001) }\end{array}$ & $\begin{array}{l}\text { There is no statistical significance of the effectiveness of } \\
\text { the SALs on growth by comparing countries with Bank } \\
\text { programs and those without such programs. }\end{array}$ \\
\hline Easterly (2004) & $\begin{array}{l}\text { Controlling the selection bias in sample countries, none of } \\
\text { the top } 20 \text { recipients of repeated adjustment lending are } \\
\text { able to achieve reasonable growth. }\end{array}$ \\
\hline \multicolumn{2}{|c|}{ 2. Does the aid-growth relation change among regions? } \\
\hline Mosley et al. (1987) & $\begin{array}{l}\text { There is a positive impact of aid on growth in Asian and } \\
\text { Latin America, but a negative impact in Africa. }\end{array}$ \\
\hline $\begin{array}{l}\text { Hansen and Tarp } \\
\text { (2001) }\end{array}$ & $\begin{array}{l}\text { The effect on the growth impact of aid is captured through } \\
\text { the introduction of country specific effects in the } \\
\text { regressions. }\end{array}$ \\
\hline Dalgaard et al. (2004) & $\begin{array}{l}\text { Using a climate-related variable, aid is found to be less } \\
\text { effective in the geographic tropics. }\end{array}$ \\
\hline \multicolumn{2}{|c|}{$\begin{array}{l}\text { 3. Does the effectiveness of aid on growth depend on the quality of policy in } \\
\text { recipient countries? }\end{array}$} \\
\hline $\begin{array}{l}\text { Burnside and Dollar } \\
(2000)\end{array}$ & $\begin{array}{l}\text { Aid contributed positively to growth, but only in good } \\
\text { policy environments using an index of } 3 \text { policies (budget } \\
\text { surplus, the inflation rate and the openness). }\end{array}$ \\
\hline $\begin{array}{l}\text { Collier and Dollar } \\
(2001)\end{array}$ & $\begin{array}{l}\text { The good-policy hypothesis is supported using the World } \\
\text { Bank's Country Policy and Institutional Assessment } \\
\text { (CPIA) as the measure of policies. }\end{array}$ \\
\hline $\begin{array}{l}\text { Hansen and Tarp } \\
(2001)\end{array}$ & $\begin{array}{l}\text { In a diminishing returns model, aid increases the growth } \\
\text { rate, but this is not conditional on the policy index. }\end{array}$ \\
\hline $\begin{array}{l}\text { Easterly et al. (2003) } \\
\text { and Ram (2004) }\end{array}$ & $\begin{array}{l}\text { The aid-policy interaction parameters are found to be } \\
\text { fragile. }\end{array}$ \\
\hline \multicolumn{2}{|c|}{ 4. Does aid reduce poverty? } \\
\hline Mosley et al. (2004) & $\begin{array}{l}\text { Aid is shown to have a significant positive impact on pro- } \\
\text { poor expenditure, which in turn has a significant negative } \\
\text { impact on poverty rates. }\end{array}$ \\
\hline \multicolumn{2}{|c|}{ 5. World Bank Lending and trade regime } \\
\hline $\begin{array}{l}\text { Krueger and } \\
\text { Rajapatirana (1999) }\end{array}$ & $\begin{array}{l}\text { The Bank supported trade policy reform and the Bank } \\
\text { policies led to more trade liberalisation than otherwise, } \\
\text { based on a sample of } 20 \text { countries for the period 1985-96. }\end{array}$ \\
\hline \multicolumn{2}{|c|}{ 6. Does aid have catalytic effects? ${ }^{6}$} \\
\hline
\end{tabular}

\footnotetext{
${ }^{6}$ The theory of catalysis is that the multilateral institutions such as IMF and World Bank help countries to send out a positive signal, via IMF agreements or policy-based conditionality, about the credibility of economic reform, and this, in turn, increases the willingness of private capital markets to lend (Bird and
} 


\begin{tabular}{|l|l|}
\hline Faini et al. (1991) & $\begin{array}{l}\text { There is a significant negative correlation between } \\
\text { multilateral lending and net private credit. }\end{array}$ \\
\hline $\begin{array}{l}\text { Bird and Rowlands } \\
(2001)\end{array}$ & $\begin{array}{l}\text { The overall results suggest the absence of a catalytic effect } \\
\text { of World Bank lending. }\end{array}$ \\
\hline Evrensel (2004) & $\begin{array}{l}\text { The cost of multilateral debt being lower than that of } \\
\text { private lending has encouraged the low income countries' } \\
\text { to access official lending more than the expensive private } \\
\text { lending, as private debt is more closely related to the } \\
\text { reputation and credibility of the recipients in implementing } \\
\text { policy reforms. }\end{array}$ \\
\hline
\end{tabular}

Overall, although an aid-investment-growth link is found to be weak in the financing gap model, it is found to be significant in a neoclassical approach. There is a mixed result whether the effectiveness of aid on growth depends on the quality of policy in recipient countries or not. An aid-growth link is generally found to be strong in the multivariate regressions, where the target variable is regressed on a range of hypothetical explanatory variables. The model developed in the next section takes the financing gap model of the World Bank as the starting point, and integrates it with the financial programming framework of the IMF to take account of the key policy variables in a growth context.

\section{An adjustment-led growth model}

The emergence of structural adjustment loans appears to have blurred the functions of the World Bank and the IMF. The relevant focus of the IMF is on the design of policies aimed at stabilising the economy and managing aggregate demand, looking primarily at the immediate exchange rate and balance of payments problems, whereas the major focus of the Bank is more on structural policies aimed at influencing aggregate supply and longer term development (Bird and Rowlands, 1997, Przeworski

Rowlands, 1997 and 2001). Therefore international financial institutions' lending is expected to have a positive effect on other capital flows, thereby contributing to economic growth. 
and Vreeland, 2000 and Marcus, 2002). However, with the Bank's participation in the overall policy framework, an overlap with the IMF was inevitable and this raised many difficulties (Krueger and Rajapatirana, 1999, p.720).

Moreover, there is little evidence of a valid effectiveness of the World Bank's policy- based structural lending (SAL) as discussed in the previous section. It is argued that the design of structural adjustment programs under the auspices of the World Bank is open to debate (Bird and Rowlands, 1997), e.g. market-determined policies may not always be effective towards economic development; financial liberalisation may perversely affect the credit availability in the private sector and may adversely affect economic growth. Thus a model combining macroeconomic policies with economic growth $^{7}$ may capture these concerns, and provide a better picture in determining the growth impact of international lending.

The IMF policy model is discussed in Appendix 1. Given the short-run stabilization target in equation [A8], a model of capacity output establishing a link between financing and capacity growth is needed. The World Bank's Revised Minimum Standard Model (RMSM) provides such an approach, which is based on the simple framework of Harrod-Domar growth model. The empirical literature has adopted a multiple linear regression relating growth in the recipient country, as a dependent variable, to aid, saving and private capital inflows, as independent variables. This simple model implies that aid has some kind of straightforward 'leverage' on growth. Empirically, it was found to be very difficult to establish any statistically significant correlation between aid and growth in this simple Harrod-Domar model (Mosley et al., 1987).

\footnotetext{
${ }^{7}$ See, for example, Fischer (1993), and Bleaney (1996).
} 
Mosley et al. (1987) expanded the simple Harrod-Domar model by incorporating changes in the literacy rate and in export values with the view to examining the effects of aid disbursement, not only on growth, but also on the spending pattern of the public and the behaviour of private sectors through the price system. They argue that the possibility of leakages into non-productive expenditure in the public sector and of the transmission of negative price effects to the private sector may be one of the contributory factors for the inconclusive relationship between aid and growth. Easterly (1999) redefined the Harrod-Domar model as the financing gap model: future growth depends on present investment, and the aid fills the gap between domestic investment and the total investment required to achieve the growth target. The financing gap model provided the analytical foundations for the World Bank's aid programs. The emphasis in the World Bank's RMSM is to ascertain whether the domestic and external financing available to a particular country is adequate to achieve a target for economic growth. In the financing gap model, World Bank loans are usually determined to fill the "financing gap" - the gap between the level of investment needed to achieve a certain level of economic growth and the actual level of saving available in the aid-recipient country.

The model can be described as follows. In a closed economy, savings (S) equal investment (I): $I=S$. Private savings $\left(\mathrm{S}^{p}\right)$ are an increasing function of income $(Y)$ : $S^{p}=s Y, 0<s<1, I=d K=\sigma d Y$, where $\sigma>1$; and $d Y$ denotes the change in nominal output (GDP), $d K$ the change in capital stock or investment $(I)$. Increase in domestic investment can raise capital accumulation and hence higher output growth, depending eventually on the productivity of capital, given by the inverse of ICOR $(\sigma)$. From the national income accounting identity 
$Y=C^{p}+I+G+X-Z$ or, $I=\left(Y-T-C^{p}\right)+(T-G)+(Z-X)$

$\Rightarrow I=S^{p}+F D+T D$

where $\mathrm{C}^{\mathrm{p}}$ is private consumption, $\mathrm{G}$ is government expenditure, $\mathrm{X}$ - Exports in domestic currency; $\mathrm{Z}$ - Imports in domestic currency, $T$ is tax, TD and FD are trade and fiscal deficits respectively. Investment is determined by foreign exchange availability in the long run, if savings (both private and public) are a constraint. Substituting $I=\sigma d Y$ in the above expression,

$\sigma d Y=s Y+T D+F D$ or, $\sigma d Y=s\left(Y_{0}+d Y\right)+T D+F D$

Thus, $d Y=\frac{s}{\sigma-s} Y_{0}+\frac{1}{\sigma-s}(T D+F D)$

Assuming $Y=P y$, where $P$ and $y$ are prices and real output respectively; and replacing $\mathrm{d} Y$ by $d Y=P_{0} d y+y_{0}\left(\theta d e+(1-\theta) d P_{D}\right)^{8}$, we get $P_{0} d y+y_{0}\left(\theta d e+(1-\theta) d P_{D}\right)=\frac{s Y_{0}}{(\sigma-s)}+\frac{1}{[\sigma-s]}(T D+F D)$

$\Rightarrow d y=\frac{s y_{0}}{(\sigma-s)}+\frac{1}{(\sigma-s) P_{0}}(T D+F D)-\frac{y_{0} \theta}{P_{0}} d e-\frac{y_{0}(1-\theta)}{P_{0}} d P_{D}$

where $d P_{D}$ reflects the stabilization target as in [A8] in the Appendix. Khan et al. (1990) suggested reconciling the models of the IMF and World Bank by including monetary accounts to the RMSM. Given the Bank's focus on real variables and the Fund's emphasis on financial variables, the two institutions' macroeconomic

\footnotetext{
${ }^{8}$ See Appendix for the derivation of this relation. Given the weaknesses of the financing gap model that the model is built upon the national accounting identity, we integrate it with the IMF model to emphasize the additional structural features within a policy framework. Moreover the accounting identities do not usually match the data (as in Easterly (1999)), providing room for empirical testing of the relations.
} 
approaches are usually merged into a general model. Equations [1] and [A8] constitute the model of adjustment and growth. Substituting equation [A8] in [1], we get

$$
\begin{aligned}
d y= & \frac{s Y_{0}(1+m v)-v(\sigma-s)\left(X-m Y_{0}+F\right)}{P_{0}(\sigma-s)(1+m v)}+\frac{1}{(\sigma-s) P_{0}}(T D+F D) \\
& -\left[\frac{v R_{0}^{*}}{P_{0}(1+m v)}\right] d e-\frac{v}{P_{0}(1+m v)} d D C
\end{aligned}
$$

The 'twin deficit', particularly trade deficit, in this equation can be financed by surplus on the capital account in the balance of payments, which would include concessional lending, with other types of financial flows, namely direct, portfolio and other investment flows along with private debt flows.

Assuming $T D=d W B L$, where $d W B L$ is the change in external lending (or World Bank lending), and a constant fiscal deficit which is financed by domestic credit, $F D=d D C$, we can replace the twin deficit with these two resource flows variable as an appropriate way of carrying out the empirical investigation of the extent of impact of external finance, mainly World Bank lending on economic growth. In low income countries, between private and multilateral sources of debt flows, World Bank lending constitutes a bigger share in total disbursements (see Evrensel, 2004).

Replacing $T D+F D$ with changes in World Bank lending and domestic lending (captured in domestic credit), the growth equation can be reformulated as follows:

$$
\begin{aligned}
d y= & -\frac{v(X+F)}{P_{0}(1+m v)}+\left(\frac{s}{\sigma-s}+\frac{m v}{1+m v}\right) y_{0}+\frac{1}{(\sigma-s) P_{0}} d W B L-\frac{v R_{0}^{*}}{P_{0}(1+m v)} d e \\
& +\frac{(1+m v)-v(\sigma-s)}{P_{0}(\sigma-s)(1+m v)} d D C
\end{aligned}
$$

In this reduced form specification, the coefficient on initial GDP is likely to be negative because higher $m$ (income elasticity of import demand) could worsen net exports and therefore the impact on real output growth could be negative under plausible assumptions of the other parameters. Since $\sigma>1$ and $s<1, \sigma-s>0$, which makes the 
coefficient associated with WBL as positive. The transmission mechanism can therefore be given as follows: higher World Bank lending contributes to better infrastructure, which stimulates investment and thus sustains higher growth.

Generally, in order for saving, whether it originates in domestic markets or international lending (or aid), to affect output most effectively, countries need to be equipted with reasonably developed institutions and legal systems. However, in the absence of relevant aggregate institutional variables, we consider Burnside and Dollar's (2000) policy index as a proxy reflecting the policy environment. Burnside and Dollar developed an index of three policies (budget surplus, the inflation rate and the openness), known as the Burnside and Dollar policy index, which takes into account the country's fiscal, monetary and trade policies, in order to capture the quality of a country's policies and macroeconomic environments. This is based on the argument that growth of developing economies depends to a large extent on their own economic policies. A good macroeconomic policy environment could imply improving institutions, which could enable the Bank's lending to be smoothly converted to production capability, partly addressing the problem that could arise from omitted variable bias ${ }^{9}$.

The World Bank lending program focuses on the development efforts involving its soft-lending window - International Development Association (IDA). The lending priorities in the Bank's program include sectors such as infrastructure (roads, transport,

\footnotetext{
${ }^{9}$ The introduction of the policy index may also mitigate the selection bias. For the issues related to selection bias and how to circumvent it, see Glick et al. (2004). Glick et al. argue that the selection bias may be circumvented by controlling such factors as macroeconomic and political environment and financial development, which are specific to individual countries.
} 
power, water supply and sanitation), irrigation and urban development (to support both accelerated growth and improved service delivery), human development (education, health, social protection) and rural livelihoods with an emphasis on community-driven approaches. All these developmental spending have a complementarity effect on private investment and thereby economic growth (see Mallick, 2001). ${ }^{10}$ Given the developmental importance of the World Bank lending, the empirical estimation involves 30 representative developing countries from four different regions to test the hypothesis in the following section.

\section{Panel Econometric Evidence}

Equation [2] involves the following variables: real output (GDP), world-bank lending (WBL), exchange rate (EXR), domestic credit (DCR) and price level (CPI). As the multilateral institutions regard economic development as the long-run steady-state path of development, not short-term economic growth in business cycles, it is essential that we use output per capita as the policy target, instead of using annual output growth as shown in the model in the previous section. The sample period covers 1970-2001 (32 years) for 30 countries. The World Bank lending used in this paper includes both IBRD and IDA loans. ${ }^{11}$ The detailed notes on data sources and definitions are included in Appendix 2.

\footnotetext{
${ }^{10}$ For a review of the existing models on this issue, see also Granville and Mallick (2005).

${ }^{11}$ Although the effect of concessional and non-concessional loans on growth may differ, the empirical study is based on the combined loans on the following grounds. First, our primary objective is to investigate the overall effectiveness of World Bank loans. Second, over the sample period, the disbursements of the two types of loans are quite fragmentary, e.g. recipients receive IBRD for some period and then IDA for some other period, or both loans during the same period. IBRD lends mainly to
} 
Panel unit roots ${ }^{12}$ indicate that the variables are non-stationary. As the time dimension is not sufficient enough to carry out panel cointegration tests, a theoretical long-run relation postulated in the previous section suggests estimating an errorcorrection model. Following equation [2], a long-run relation between the variables in levels can be specified as follows:

$\ln G D P_{i t}=\alpha_{0}+\alpha_{1} \ln W B L_{i t}+\alpha_{2} \ln D C R_{i t}+\alpha_{3} \ln E X R_{i t}+\alpha_{4} \ln C P I_{i t}$

In equation [2], as an initial price variable enters all the coefficients, we include CPI as another variable influencing output in the empirical model. It could be argued that the above equation ignores the possible effects of the IMF on the policy variables. However, empirical studies tend to show that on average IMF programs do not statistically significantly alter policy variables even during the program years (see e.g. Doroodian, 1993 and Evrensel 2002), therefore our model largely avoids bias caused by any IMF-related omitted variables.

Given this long-run relation, the following error correction model can be specified:

$$
\begin{aligned}
& \Delta \ln G D P_{i t}=\beta_{0}-\beta_{1}\left(\ln G D P_{i t-1}-\alpha_{0}-\alpha_{1} \ln W B L_{i t-1}-\alpha_{2} \ln D C R_{i t-1}-\alpha_{3} \ln E X R_{i t-1}-\alpha_{4} \ln C P I_{i t-1}\right)+ \\
& +\sum_{j=1}^{p} \gamma_{j} \Delta \ln G D P_{i t-j}+\sum_{j=0}^{p} \delta_{j} \Delta \ln W B L_{i t-j}+\sum_{j=0}^{p} \eta_{j} \Delta \ln D C R_{i t-j}+\sum_{j=0}^{p} \lambda_{j} \Delta \ln E X R_{i t-j}+\sum_{j=0}^{p} \mu_{j} \Delta \ln C P I_{i t-j}
\end{aligned}
$$

middle-income countries using funds borrowed at commercial rates in world capital markets. IBRD loans are repayable over a 10-20 year period at interest rates slightly higher than those the Bank pays to borrow funds. IDA makes loans to the world's poorest countries. IDA loans are funded with money contributed by donor countries. IDA lends without interest charges, and principal repayments start after a 10-year period stretching over 20-30 years depending on the situation (Sanford, 2002). Our data include both concessional (IDA) and nonconcessional (IBRD) WB loans

${ }^{12}$ The panel unit root test results are available upon request from the authors. 
This error correction model satisfies three key properties: first, it corresponds to the adjustment lending linked growth model derived in equation [2] in first differences; second, the $\beta_{1}$ coefficient associated with the long-run relationship between the variables, especially the lagged level of income per capita $\left(\ln G D P_{i t-1}\right)$ would reflect the speed of adjustment among this selected sample of developing countries; finally, $\alpha_{i}$ 's can be interpreted as long-run parameters for the conditional policy variables.

Further, if the error-correction term is ignored from equation [3], the equation will be similar to a dynamic panel specification of Arellano and Bond (1991). We consider the following dynamic panel model,

$$
\ln G D P_{i t}=\sum_{j=1}^{p} \rho_{j} \ln G D P_{i t-j}+\phi_{1} \ln W B L_{i t}+\phi_{2} \ln D C R_{i t}+\phi_{3} \ln E X R_{i t}+\phi_{4} \ln C P I_{i t}+\varsigma_{i}+\varepsilon_{i t}
$$
where $\varsigma$ is the individual effect and $\varepsilon$ is the error term.

And first differencing this specification eliminates the individual effect, and thus the equation can be written as follows:

$$
\Delta \ln G D P_{i t}=\sum_{j=1}^{p} \rho_{j} \Delta \ln G D P_{i t-j}+\phi_{1} \Delta \ln W B L_{i t}+\phi_{2} \Delta \ln D C R_{i t}+\phi_{3} \Delta \ln E X R_{i t}+\phi_{4} \Delta \ln C P I_{i t}+\varepsilon_{i t} \quad \text { [4]. }
$$

This equation is similar to [3] in the absence of the error correction term. Both an error correction model - which includes the long run coefficients - and a dynamic panel model have been estimated to show the robustness of the coefficients of the impact of international lending on economic growth within a panel data framework. In the ECM, although the dependent variable is first-differenced, the model by construction examines the long-run relationship between the levels of explanatory variables, whereas the non-ECM or dynamic panel models with the first-differenced variable as the dependent variable, on the other hand, are supposed to examine the growth rates of the examined variables. 
Equations [3] and [4] are estimated by augmenting with the policy-index. Starting with higher lags, a general-to-specific approach has been followed to exclude variables depending on their level of significance. Results of equation [3] and [4] are presented in Table 2 (see Models 1 and 2). In both cases, the important finding is that World Bank lending has a positive significant impact on economic growth in our sample of countries. The policy environment turns out to be significant, although the magnitude of the impact is relatively small. Country-specific residuals obtained from estimated coefficients in Model 1 appear to reflect stationarity in residuals supporting an Engle-Granger type of residual test for cointegration ${ }^{13}$. However, there could still be possible endogeneity bias between WBL and GDP.

As WBL has been considered here as exogenous, there could be concern about simultaneity bias in our regressions due to potential endogeneity (Hadjimichael et al. 1995; Boone, 1996; Burnside and Dollar, 2000; and Hansen and Tarp 2001). The current allocation of WBL may be influenced by past periods' growth rates. In order to circumvent the simultaneity bias, we further estimate equation [4] by 2SLS and also using GMM technique with instrumental variables (see Models 3 and 4 in Table 2). We have considered several instrumental variables to take into account possible interaction effect between WBL and GDP in a non-linear way such as a WBL-GDP or WBL-POLICY multiplicative term and a WBL squared variable in both 2SLS and GMM estimations, including the lagged endogenous variables to satisfy the order condition.

\footnotetext{
${ }^{13}$ Given the limited number of time series observations, which approximately equal the number of crosssections in this sample, a panel cointegration method is not considered suitable.
} 
The key finding is that the World Bank lending steadily exerts the positive impact on the rate of growth in GDP per capita in both long-run and short-run. It appears that the positive aid-growth link is robust to the model specification and econometric techniques. In the long-run, the WBL elasticity shows around 0.02, whereas in the short-run, it is larger, between $0.02-0.25$, reflecting the larger initial impact on the rate of growth in per capita GDP ${ }^{14}$. Heller and Gupta (2001) argued that if ODA were spent entirely on imports, the country's balance of payments would be unchanged; any increase in imports would be completely financed by foreign inflows, and the inflows would have no direct impact on the country's money supply or on aggregate demand. If a significant share of foreign inflows were spent on non-traded goods, it is possible that the price of domestic goods and services would go up. It then causes an exchange rate appreciation in real terms and worsens the current account balance, thereby slowing down growth. The finding of the positive link between WB lending and the GDP growth in the current study implies that neither of the mechanisms may be working in the sample countries in this study.

Estimates with regard to changes in other macroeconomic variables are also broadly consistent in terms of sign in these models, and they appear to comply with the standard interpretations. Credit growth does have a positive impact on output growth in the short run across different models, but it does not have significant impact in the long-run. Hence, DCR, although an exogenous variable, is excluded in the error

\footnotetext{
${ }^{14}$ In the empirical literature, the aid coefficient in a growth regression is more likely to be larger than this. Yet, a similar result can be found, for example, in the empirical work by Hansen and Tarp (2001) with the coefficient of 0.044 for 56 countries (Table 1, p.551), and 0.09 for 45 countries (Table 3, p.560) with the dependent variables of GDP per capita. Burnside and Dollar (2000) also found the coefficient of 0.036 (Table 3, p.854).
} 
correction term in Table 2. The fact that an increase in domestic credit increases the growth rate of per capita GDP in the short run supports the natural rate hypothesis in macroeconomics: in the long-run any increase in credit is absorbed in the level of prices. This is in contrast to the sustained impact of WBL on real output growth both in the short- and long-run. The coefficient of the nominal exchange rate is positive, but not statistically significant at the 5\% level in the long-run, while it has a significant negative impact on per capita GDP growth in the short-run. Following depreciation domestic import prices rise, but import volumes may not fall due to agreed contracts or the consumers' tastes. It is worth noting that LDCs in general rely on non-fuel primary commodities in export, which are likely to have a low price elasticity, i.e. a fall in the export price may not contribute to an increase in export volume. This situation worsens the current account balance, so the impact on the GDP is negative in the short run.

In the dynamic panel model, there exists a trade-off between inflation and growth both in the short- and long-run, except in the static panel in short-run. A negative relationship between inflation and growth reflects macroeconomic stability being the one of the key factors in economic growth. The absence of a trade-off in the short-run static panel could also suggest a nonlinear relationship, in the sense that reductions in inflation from a low (high) base have negligible (significant) impacts on growth. The finding of the highly statistically significant coefficients for almost all macroeconomic variables in the short and long run are important. In the empirical study for IMF stabilization program, the coefficients of macroeconomic variables are not always significant. For example, Doroodian (1993) failed to obtain the significant effects of macroeconomic variables (except domestic credit) in the growth equation. Hutchinson (2001), who studied the effects of IMF rescue plans and examined the output growth in relation to currency crises, obtained significant effects of real 
variables, however, inflation has shown to be insignificant. Dicks-Mireaux et al. (2000) also find insignificant effect of inflation on the rate of growth in real GDP.

As the policy index is significant in our model, then Burnside and Dollar's hypothesis that aid effectiveness is related with the 'good policies' is supported: WB lending exerts a positive impact on the GDP growth when the recipients government pursue a good policy. This result is in contrast to the insignificant effect in Hansen and Tarp (2001), who found that irrespective of the quality of policy, aid is effective on growth, but within a different model specification. Dalgaard et al. (2004) report a positive impact of the BD policy index and the coefficient is around 0.8 , whereas we find a significant coefficient of 0.02-0.03. The magnitude of the impact being small might be due to the fact that other policy variables already in our model may have captured the effect of policy changes.

Our results show that the growth rate of per capita GDP is inversely related to the level of GDP per capita with a coefficient of 0.053 . The negative significant sign indicates that the per capita GDP adjusts at the rate of $5.3 \%$ for any deviation from its equilibrium level. It can, therefore, be argued that the sample of 30 developing countries in the world displays a low speed of adjustment, as the sample countries are relatively homogenous. The implication is that economies approach some long-run level of income, which is captured by the vector of variables, namely, changes in WB lending, domestic credit, exchange rates and prices, and the growth rate falls as the economy approaches this long-run level

Our empirical evidence reveals that WBL on growth appears to exist, and that an important policy implication is that aid operations through the Bank loans should be continuously promoted. Sanford (2004), however, raised a grave concern on the resource of IDA aid. The IDA faces conflicting goals. First, the IDA's aid program 
will remain the same size it is now in real terms for the next 20 years. Second, contributions from donors will remain fixed in nominal terms for 20 years. At the same time, the IDA grant and HIPC (heavily indebted poor countries) debt reduction programs are cutting the flow of repayments in real terms. Inevitably, its sources of income might shrink, putting the future of the IDA's program at risk. It is argued that if no new money ${ }^{15}$ is contributed to offset the cost of HIPC debt forgiveness, IDA's cash balance will become negative in 2009 . The World Bank is more likely to perceive that contributions of donors to IDA should not be diminished in real terms in future decade. The continuous growth in the donor's annual payments to IDA would be crucial for rapid and sustained growth in low-income countries by improving the investment climate via private sector development.

\section{Conclusion}

This paper investigated the link between per capita GDP growth and World Bank loans among the loan recipient countries. The paper developed theoretical explanations on the link based on the financing gap model, integrating it with the financial programming framework, along with an empirical analysis. This paper provides evidence in favour of the hypothesis that 'aid' [IDA and IBRD] exerts a positive effect on growth, being conditional on other policy variables, reflecting that a complementarity effect of developmental spending on private investment influences economic growth. The developmental spending via the World Bank loans includes development of infrastructure, primary health care, education and so on. The present paper examines

\footnotetext{
${ }^{15}$ Most of the new money to fund its aid programs comes from contributions by donors such as US, European countries and Japan.
} 
the effectiveness of such lending using a theoretical policy-based approach and tests empirically with alternate econometric techniques to show the robustness of the result that aid inflows will in general affect long-run growth, conditional on policies and structural characteristics of the country concerned. Overall we find that aid has been effective in boosting growth in our sample countries, but the magnitude of the effect can depend on the country-specific macroeconomic climate. Unless the 'macroeconomic climate' is accounted for, a direct positive effect of WBL on growth rates may not hold, as in some empirical studies.

The growth effects of aid can be limited, if aid is mainly used for politicallymotivated public-sector consumption. It is possible that the positive impact of aid on growth may not hold in very poor countries, where it is more likely that aid could be misallocated into financing government consumption expenditure, as opposed to increasing productive capital formation for economic activities. This requires disaggregating investment into private and public investment, where public infrastructural investment could be financed by foreign aid and private investment is constrained by other domestic variables and external variables namely terms of trade and external market access (or external demand). Further, instead of a fixed linear relationship assumed in the present model, there is room for introducing a nonlinear production function with human capital as an extended supply side framework within which the impact of international lending could be explored. Also, in order to assess the effectiveness of the World Bank lending as growth-enhancing types of aid, detailed area or country-specific case studies would be required to overcome the sample selection bias, and to account for different macroeconomic policy regimes. 


\section{References}

Agénor, P.R., 2004, The Economics of Adjustment and Growth, Second Edition: Harvard University Press: Cambridge, MA.

Arellano, M., and S. Bond, 1991, Some Tests of Specification for Panel Data: Monte Carlo Evidence and an Application to Employment Equations, Review of Economic Studies, 58: 277-297.

Bird, G. and D. Rowlands, 1997, The Catalytic Effect of Lending by the International Financial Institutions, The World Economy, 20(7): 967-991.

Bird, G., and D. Rowlands, 2001, World Bank Lending and Other Financial Flows: Is There a Connection? Journal of Development Studies, June, 37 (5): 83-103.

Bleaney, M.F., 1996, Macroeconomic Stability, Investment and Growth in Developing Countries, Journal of Development Economics, 48 (2): 461-477.

Boone, P., 1996, Politics and the effectiveness of foreign aid, European Economic Review, 40: 289-329.

Burnside, C. and D. Dollar, 2000, Aid, policies, and growth, American Economic Review, 90: 847-868.

Collier, P., 1997, The Failure of Conditionality, in C. Gwin and J. Nelson (eds.), Perspectives on Aid and Development. Washington, DC: Overseas Development Council.

Collier, P. and D. Dollar, 2001, Can the world cut poverty in half? How policy reform and effective aid can meet international development goals. World Development, 29 (11): 1787-1802.

Conway, P., 1994, IMF lending programs: participation and impact, Journal of Development Economics, 45: 365-391.

Dalgaard, C-J., H. Hansen, and F. Tarp, 2004, On the Empirics of Foreign Aid and Growth, The Economic Journal, 114 (496): 191-216.

Dicks-Mireaux, M. Mecagni and S. Schadler, 2000, Evaluating the effect of IMF lending to low-income countries, Journal of Development Economics, 61: 495-526.

Donovan, D., 1982, Macroeconomic performance and adjustment under Fundsupported programs: the experience of the seventies, IMF Staff Papers, 29: 171-203.

Doroodian, K., 1993, Macroeconomic Performance and Adjustment under Policies Commonly Supported by the International Monetary Fund, Economic Development and Cultural Change, 41 (4): 849-864. 
Durbarry, R., N. Gemmell, and D. Greenaway, 1998, New evidence on the impact of foreign aid on economic growth, CREDIT research paper No.98/8, University of Nottingham.

Easterly, W., 1999, The Ghost of financing gap: testing the growth model used in the international financial institutions, Journal of Development Economics, 60, 423-438.

Easterly, W., 2004, What did structural adjustment adjust? The association of policies and growth with repeated IMF and World Bank adjustment loans, Journal of Development Economics, 20, 1-22.

Easterly, W., R. Levine, and D. Roodman, 2003, New data, new doubts: Revisiting 'Aid, Policies, and Growth', Working Paper Number 26, Center for Global Development: Washington DC.

Evrensel, A.Y., 2002, Effectiveness of IMF-Supported Stabilization Programs in Developing Countries, Journal of International Money and Finance, 21 (5): 565-587.

Evrensel, A.Y., 2004, Lending to developing countries revisited: changing nature of lenders and payment problems, Economic systems, 28, 235-256.

Faini, R., J. de Melo, A. Senhadji-Semlali and J. Stanton, 1991, Macro Performance Under Adjustment Lending, in (eds.) C. Gilbert and D. Vines, The World Bank: Structure and Policies, Cambridge: CEPR and Cambridge University Press.

Fischer, S., 1993, Role of Macroeconomic Factors in Growth, Journal of Monetary Economics, 32: 485-512.

Frey, B.S. and F. Schneider, 1986, Competing Models of International Lending Activity, Journal of Development Economics, 20, 225-245.

Gilbert, C., A. Powell, and D. Vines, 1999, Positioning the World Bank, The Economic Journal, 109 (459): 598-633.

Glick, R., X. Guo and M. Hutchison, 2004. Currency Crises, Capital Account Liberalization, and Selection Bias, Santa Cruz Center for International Economics, Working Paper No 1037, UC Santa Cruz.

Granville, B., and S.K. Mallick, 2005, How best to link poverty reduction and debt sustainability in IMF-World Bank Models? International Review of Applied Economics, January, 19 (1): 67-85.

Hadjimichael, M., D. Ghura, M. Muhleisen, R. Nord, and E. Ucer, 1995, Sub Saharan Africa: growth, savings and investment, 1986-93. IMF Occasional paper 118, International Monetary Fund: Washington DC.

Hansen, H. and F. Tarp, 2001, Aid and growth regression, Journal of Development Economic, 64: 547-570. 
Hutchison, M. (2001). A Cure or Worse than the Disease? Currency Crises and the Output Costs of IMF-Supported Stabilization Programs, NBER Working Paper 8305 (May), Cambridge: MA.

Khan, M.S., Montiel, P.J. \& Haque, N.U. (1990), Adjustment with Growth: Relating the Analytical Approaches of the IMF and the World Bank, Journal of Development Economics, 32, January, 155-79.

Krueger A. O and S. Rajapatirana (1999), The World Bank Policies Towards Trade and Trade Policy Reform, World Economy, 22(6): 717-740.

Lensink, R. and O. Morrissey (2000), Aid Instability as a Measure of Uncertainty and the Positive Impact of Aid on Growth, Journal of Development Studies, 36 (3): 30-48.

Mallick, S.K. (2001), Dynamics of Macroeconomic Adjustment with Growth: Some Simulation Results, International Economic Journal, 15 (1), Spring, 115-139.

Marcus, E. (2002), The History of the World Bank, Economic Journal, 112 (477), February 119-135.

Mosley, P., J. Hudson and A. Verschoor (2004), Aid, Poverty Reduction and the 'New Conditionality', Economic Journal, 114 (496): 217-243.

Mosley, P., J. Harrigan and J. Toye (1991), Aid and Power: the World Bank and Policy-Based Lending, 2 volumes, London: Routledge.

Mosley, P., J. Hudson and S. Horrell (1987), Aid, the public sector and the market in less developed countries, Economic Journal, 97, 616-641.

Obstfeld, M. (1999), Foreign Resource Inflows, saving, and growth, in SchmidtHebbel, K. and L. Serven (eds.), The economics of Saving and Growth. Cambridge University Press, Cambridge, UK, Chapter 5, 107-146.

Polak, J.J. (1998), The IMF monetary model at 40, Economic Modelling, July, 15 (3): 395-410.

Przeworski, A., and J. Vreeland (2000), The effect of IMF programs on economic growth, Journal of Development Economics, 62: 385-421.

Ram R. (2004), Recipient country's 'policies' and the effect of foreign aid on economic growth in developing countries: additional evidence Journal of International Development, 16(2): May, 201-211.

Sanford, J. E. (2002), World Bank: IDA loans or IDA Grants? World Development, 30 (5): 741-762.

Sanford, J.E. (2004), IDA Grant and HIPC Debt Cancellation: Their Effectiveness and Impact on IDA Resources, World Development, 32(9): 1579-1607. 


\section{Appendix 1: A Macroeconomic Policy Model}

The current IMF approach, which has been the basic policy framework in many developing countries, can be combined with the World Bank growth approach. ${ }^{16}$ The following three basic macroeconomic relationships characterise the Fund model:

1. National income accounting balance: $Y=C+I+X-Z$

or, Saving-Investment balance: $I=S+(Z-X)$

2. Balance sheet identity for the banking system: $d M=d D C+d R$

where M - Money Supply; DC - Domestic Credit; R - Reserve expressed in domestic currency; $\mathrm{R}$ and $\mathrm{M}$ are endogenous; $\mathrm{DC}$ is a policy variable under the control of the monetary authorities. The model assumes that income velocity of money is constant [Velocity: $v=\mathrm{Y} / \mathrm{M}]$.

3. Money market is required to be in flow equilibrium $\left(\mathrm{dM}=\mathrm{dM}^{\mathrm{d}}\right): d M=\frac{1}{v} d Y$

The definition of change in reserves includes the exchange rate changes. Thus change in reserve can be defined as:

$R=e R^{*} \Rightarrow d R=e d R^{*}+R_{0}^{*} d e$

$R^{*}$ are reserves expressed in foreign currency; $R_{o}^{*}$ is the initial period level of $R^{*}$, e is the domestic currency price of a unit of foreign currency. This equation assumes that both the variables are endogenous, in which case the equation can be interpreted as a definition of 'exchange market pressure', but in this model de can be changed exogenously. Model can be solved for the change in the stock of international reserves $\mathrm{R}$ as a function of $v$ and $\mathrm{Y}$, as well as of the monetary policy instrument DC by substituting [A3] into [A2]:

\footnotetext{
${ }^{16}$ For a recent survey of the financial and growth programming models, see Agénor (2004, ch.9).
} 
$e d R^{*}=\frac{1}{v} d Y-d D C-R_{0}^{*} d e$

Given a target value for the change in reserves and projections for $v$ and $\mathrm{Y}$, required expansion in the stock of credit can be reformulated from equation [A4].

External balance or balance-of-payments (BOP) identity can be written as:

$e d R^{*}=X-m\left(Y_{0}+d Y\right)+F, \quad 0<\mathrm{m}<1$

F - Net capital inflows in domestic currency.

Khan et al. (1990) distinguish explicitly between changes in real and nominal output. In the original IMF model (see Polak, 1998), real output (y) is assumed to be exogenous:

$Y=P y$, or,$d Y=P_{0} d y+y_{0} d P$

where $P_{0}$ and $y_{0}$ stand for the initial period price level and real income respectively.

$P$, which is endogenous, can be expressed as a weighted average of the price of importables $\left(P_{Z}\right)$ and the price of domestic output $\left(P_{D}\right)$, and written as $d P=\theta d P_{Z}+(1-\theta) d P_{D}$ and $d P_{Z}=P_{Z}{ }^{*} d e=d e$, where $P_{Z}{ }^{*}$ is the price of foreign goods measured in foreign currency. It is assumed for convenience that $P_{Z}{ }^{*}=1^{17}$. $\theta$ is the share of imports in the price index.

Substituting the above relations in [A4] and solving the resulting expression for the change in reserves yields the monetary equilibrium as follows:

$$
e d R^{*}=\frac{1}{v}\left(P_{0} d y+\theta y_{0} d e+(1-\theta) y_{0} d P_{D}\right)-d D C-R_{0}^{*} d e
$$

The two main targets in Fund model are changes in foreign exchange reserves and inflation. The two instruments are the domestic credit and the nominal exchange rate. Substituting $d y$ in the BOP identity [A5]

\footnotetext{
${ }^{17}$ The assumption of $\mathrm{Pz}^{*}=1$ is a simplifying one. Clearly the price of importables may not be constant in reality, and oil shocks, for example, will matter in many oil-dependent economies.
} 
$e d R^{*}=X-m\left(Y_{0}+P_{0} d y+\theta y_{0} d e+(1-\theta) y_{0} d P_{D}\right)+F$

The model's solution for inflation can be determined by simultaneously solving monetary equilibrium equation [A6] and external equilibrium [A7]: $d P_{D}=\frac{v\left(X-m Y_{0}+F\right)}{y_{0}(1-\theta)(1+m v)}+\frac{1}{(1-\theta)}\left[\frac{v R_{0}^{*}}{y_{0}(1+m v)}-\theta\right] d e+\frac{v}{y_{0}(1-\theta)(1+m v)} d D C-\frac{P_{0}}{y_{0}(1-\theta)} d y$

The changes in exchange rate and domestic credit have a positive impact on inflation, while there is a trade-off relationship between growth and inflation. Since the Fund model assumes real output to be fixed in the short run, $d y=0$. Thus, the inflation model can be written as follows:

$d P_{D}=\frac{v\left(X-m Y_{0}+F\right)}{y_{0}(1-\theta)(1+m v)}+\frac{1}{(1-\theta)}\left[\frac{v R_{0}^{*}}{y_{0}(1+m v)}-\theta\right] d e+\frac{v}{y_{0}(1-\theta)(1+m v)} d D C$

\section{Appendix 2: Notes on Data sources and Definitions}

The sample period is from 1970 to 2001 (32 years) for 30 countries. The selection of country is determined by the data availability in order to obtain a balanced panel dataset. Thus the empirical estimation involves the following group of 30 representative developing countries from the four different regions:

Asia: India, Indonesia, Malaysia, Nepal, Pakistan, Philippines, Sri Lanka, Thailand;

Africa: Cameroon, Ghana, Kenya, Morocco, Niger, Senegal, Tanzania, Tunisia;

Latin America: Argentina, Bolivia, Brazil, Chile, Costa Rica, Ecuador, El Salvador, Honduras, Mexico, Peru, Uruguay;

Middle East: Egypt, Jordan, Turkey.

The sources of data are as follows: 


\begin{tabular}{|l|l|l|}
\hline$W B L$ & IDA and IBRD lending & WDI (World development indicators) \\
\hline$C P I$ & Consumer Price Index & IFS line 64 (except Brazil: wholesale prices) \\
\hline$E X R$ & $\begin{array}{l}\text { Exchange rate (domestic } \\
\text { currency/US\$) }\end{array}$ & IFS period average official rate \\
\hline$D C R$ & Domestic credit & IFS line 32 \\
\hline$G D P$ & Real GDP per capita & $\begin{array}{l}\text { WDI (except Jordan and Tanzania where } \\
\text { nominal GDP/CPI divided by population } \\
\text { from IFS) }\end{array}$ \\
\hline
\end{tabular}

\section{The policy index data:}

Burnside and Dollar's (2000) constructed a policy index:

BD policy index $=1.28+6.85$ budget surplus -1.4 inflation +2.16 trade openness.

The parameters are derived by OLS. Following Burnside and Dollar (2000), Hansen and Tarp (2001) and Ram (2004), we have derived the similar policy index with inflation, the ratio of budget surplus/deficit to GDP and the ratio of trade to GDP as a proxy for openness, and specified as an additional regressor in the model, in order to examine whether the positive relationship between GDP and WB lending are related with the quality of policies in the recipient countries.

Inflation is derived from CPI, and budget deficit/surplus from IFS (line 80). Trade to GDP is collected from WDI. The BD's equation is calculated using the same parameter. There are missing data, mainly in Niger, Senegal and Tanzania. This is mainly due to the missing data of budget in IFS, though some budget data from WDI filled some missing data. 
Table 2: Estimating the impact of World Bank lending using alternative models Dependent variable: $\mathrm{D}(\mathrm{GDP})$ Model 1 Model 2 Model 3 Model 4 Model 5

\begin{tabular}{|c|c|c|c|c|c|}
\hline Constant & $\begin{array}{c}0.326^{* *} \\
(0.069) \\
\end{array}$ & $\begin{array}{c}0.012 \\
(0.053) \\
\end{array}$ & $\begin{array}{c}-0.003 * * \\
(0.001) \\
\end{array}$ & $\begin{array}{l}-0.007 \\
(0.004) \\
\end{array}$ & $\begin{array}{c}0.003 \\
(0.003) \\
\end{array}$ \\
\hline GDP(-1) & $\begin{array}{c}-0.053^{* *} \\
(0.008) \\
\end{array}$ & - & - & - & - \\
\hline WBL(-1) & $\begin{array}{c}0.018 * * \\
(0.004) \\
\end{array}$ & - & - & - & - \\
\hline $\operatorname{EXR}(-1)$ & $\begin{array}{c}0.020 \\
(0.012) \\
\end{array}$ & - & - & - & - \\
\hline CPI(-1) & $\begin{array}{l}-0.022 \\
(0.011) \\
\end{array}$ & - & - & - & - \\
\hline$\Delta(\mathrm{WBL})$ & - & - & $\begin{array}{c}0.245^{* *} \\
(0.031) \\
\end{array}$ & $\begin{array}{c}0.186^{* *} \\
(0.046) \\
\end{array}$ & $\begin{array}{c}0.161 \text { ** } \\
(0.028)\end{array}$ \\
\hline$\Delta(\mathrm{DCR})$ & $\begin{array}{l}0.050^{*} \\
(0.021) \\
\end{array}$ & $\begin{array}{l}0.041^{*} \\
(0.018) \\
\end{array}$ & - & - & - \\
\hline$\Delta(\mathrm{EXR})$ & $\begin{array}{c}-0.139 * * \\
(0.022) \\
\end{array}$ & $\begin{array}{c}-0.158^{* *} \\
(0.018) \\
\end{array}$ & $\begin{array}{l}-0.020 \\
(0.015) \\
\end{array}$ & - & $\begin{array}{l}-0.032^{*} \\
(0.014) \\
\end{array}$ \\
\hline$\Delta(\mathrm{CPI})$ & - & - & - & $\begin{array}{l}-0.081 \\
(0.052) \\
\end{array}$ & - \\
\hline$\Delta(\mathrm{GDP}(-1))$ & $\begin{array}{c}0.222 * * \\
(0.034) \\
\end{array}$ & $\begin{array}{c}0.308 * * \\
(0.033) \\
\end{array}$ & $\begin{array}{c}0.396^{* * *} \\
(0.106) \\
\end{array}$ & $\begin{array}{c}0.761^{* * *} \\
(0.171) \\
\end{array}$ & $\begin{array}{c}0.389 * * \\
(0.115) \\
\end{array}$ \\
\hline$\Delta($ WBL $(-1))$ & $\begin{array}{c}0.025 \\
(0.022) \\
\end{array}$ & $\begin{array}{l}0.031^{*} \\
(0.015) \\
\end{array}$ & - & - & - \\
\hline$\Delta(\mathrm{DCR}(-1))$ & - & - & - & $\begin{array}{c}0.074 \\
(0.039) \\
\end{array}$ & - \\
\hline$\Delta(\mathrm{CPI}(-1))$ & $\begin{array}{c}0.089 * * \\
(0.025)\end{array}$ & $\begin{array}{l}0.052^{*} \\
(0.026) \\
\end{array}$ & $\begin{array}{c}0.021 \\
(0.014) \\
\end{array}$ & 2 & $\begin{array}{c}0.022 \\
(0.015) \\
\end{array}$ \\
\hline POLICY \# & $\begin{array}{c}0.016^{* *} \\
(0.005) \\
\end{array}$ & $\begin{array}{c}0.025^{* *} \\
(0.005)\end{array}$ & 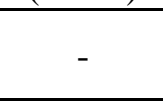 & - & 2, \\
\hline $\mathrm{N}$ obs & 765 & 738 & 801 & 816 & 801 \\
\hline R-sq & 0.275 & 0.277 & 0.174 & $0.01^{1}$ & 0.101 \\
\hline S.E. of regression & 0.038 & 0.039 & 0.043 & 0.048 & 0.042 \\
\hline \multicolumn{6}{|c|}{$\begin{array}{l}\text { Notes: * and ** indicate significance at 1\% and 5\% levels respectively (standard } \\
\text { errors in parentheses). Model 1: Panel least squares with Fixed effects and Panel } \\
\text { Corrected Standard Error(PCSE); Model 2: First-differenced model using panel } \\
\text { feasible generalized least squares (FGLS); Model 3: Model } 2 \text { using IV (Two-stage) } \\
\text { FGLS; Model 4: Arellano-Bond dynamic panel using generalized method of moments } \\
\text { (GMM); Model 5: Model } 4 \text { with period random effects. } \\
\text { \# indicates the variable being expressed in first differences in Model } 2 .\end{array}$} \\
\hline
\end{tabular}

\section{${ }^{1}$ Is it really that low? Are they adjusted R-squares?}

